\title{
ESTIMATION OF URBAN WATER DEMAND USING SYSTEM DYNAMICS MODELING FOR MADURAI CITY
}

\author{
Gokila Vani ${ }^{1}$, Ravisankar ${ }^{2}$ \\ ${ }^{1}$ Infrastructure Engineering and Management, Thiagarajar College of Engineering, Tamilnadu, India \\ ${ }^{2}$ Assistant Professor, Department of Civil Engineering, Thiagarajar College of Engineering, Tamilnadu, India
}

\begin{abstract}
Water is important for all kind activities in the present world. Estimation of urban water demand is necessary step in rapidly urbanizing world to upgrade and enhance the water infrastructure assets, sustainable water management planning, design and satisfy the future needs. For water demand estimation, Conventional mathematical models and advanced computational models are applied for estimating short and long term water demands. Though the factors considering for water demand re dynamic in nature, accurate prediction needs more iterative models. System Dynamics modeling has been chosen because it considers the socio-economic factors which are dynamic in nature. It is an iterative technique which helps to arrive at the accurate demand.

The main objectives of this study are thoroughly reviewing the water demand estimation model and formulate the System dynamics model for Madurai city which considers the socio-economic factors which are not being stable. System dynamics modeling procedures are Problem identification, Model formulation, Simulation and Validation. System Dynamics simulation results the estimation of water demand by 2040 for the selected study area. At present the demand for Madurai city is 209 MLD, the city corporation supply only 115 MLD. Based on the calculation for water demand compared with water supply, at present the city has a shortage of 94 MLD of water. Because of importance in Industries, tourism and population growth the water demand for Madurai will increase gradually on the coming years. The study results indicate that total demand of Madurai city increases in each decade and supply are being insufficient.
\end{abstract}

Keywords: Water Demand, System Dynamics, Madurai City, Water Management Etc...

\section{INTRODUCTION}

Globally, urbanization takes place more in developing countries than in the developed countries and increases in population growth decreases in the economic growth rate. At present, the people lives more in urban areas than in the rural regions. $66 \%$ of world's populations are expected to be in living in urban areas in the year of 2050.

Developing countries like India, China, Nigeria re expected to the population growth of $37 \%$ will reside in urban areas by the year of 2050. Urbanization creates the major problems which are complication in infrastructure management, exploitation of resources, increases the environmental pollution and deforestation. It has forcedly leads to the projection of resources for future years and for some management aspects.

In water and wastewater management, urbanization plays an major role. Because due to the expansion and development of cities, ground water resources are being exploited and pollutes land, water and air by the non-degradable materials and leads to climate change, global warming, destruction of species etc., Developing countries like India, water supply and management and other public utility services are being carried out by the governmental under some sort of schemes and policies. It has the services of conveying water from reservoirs, raw water treatment, supplying water through pipe networks to the urban areas, household connections, yard taps etc., The improper water supply happens due to improper maintenance of water infrastructure assets and creates the condition of shortage of water.

The word "demand" which appears in the title of this report is a technical term in economics. It denotes the quantity of a commodity which will be taken off the market at a particular price. This study is only minimally concerned with water demands in this economic sense. Rather, it primarily focuses on water requirements, needs, and usage; terms which are employed more or less interchangeably herein to denote quantities of water assumed to be largely independent of prices. Clearly, predictions of future water requirements constitute merely a first cut at estimating future demands since they ignore price. The accuracy of such initial estimates as indicators of demand depends to large extent on the costs of supply, which are entirely ignored herein. It does not follow, however, that predictions of future water requirements are of little or no value. Quite the contrary, requirements may be expected to approximately equal demands as long as water remains in relative abundance.

[ Donald T. Lauria et al., 1975]

In order to ensure reliable water supply to the residents of a city, an accurate estimate of future water demand is necessary. In India, the main reasons are available which tends us to estimate the water supply and demand are mentioned below

1. Percentage of population towards urbanization, migration. 
2. Greater economy (Per capita water usage Vs GDP , Urban area, Cultural Vs Geographic location).

3. Spatial mismatches between

- Population and Water resources

- Population and Annual rainfall

- Population and climatic conditions.

- Human development index and water resources availability.

Total water demand of India by 2025 and 2050 are $22 \%$ in 2025 and $32 \%$ in 2050.

Estimation of urban water demand is necessary step in rapidly urbanizing world to upgrade and enhance the water infrastructure assets, sustainable water management planning, design and satisfy the future needs. For water demand estimation, Conventional mathematical models and advanced computational models are applied for estimating short and long term water demands. Though the factors considering for water demand re dynamic in nature, accurate prediction needs more iterative models.

For many reasons, India have a central place in global water supply and demand projections. First, constituting more than one-third of the world's population, India is the most populous country in the world. Second, India have huge economy. Economic growth in the recent decades-since the 1980s in India has been remarkable.

\subsection{Water Demand Estimation Techniques}

Estimating water demand is different for municipal, Industrial sectors etc., Initial step in finding water demand for future years are considering the at present peak water demand and supply analysis, reviewing the methods for urban water demand estimation according to the time horizon of short, middle and long term estimation. For short term estimation, there's no need of considering more variable with limitations. It helps to provide the guidance for maintaining the operation and management. For long term estimation, it help in planning and management of infrastructure assets, helps to develop sustainable management plan for water etc., by considering the more number of factors which are dynamic in nature.

Many approaches have been proposed to forecast short- and long-term municipal water demands. The first are short-term forecasts; Linear regression, Composite model, ANN, Time series analysis, Wavelet denoizing, Monte-Carlo simulation, Fourier series, Multiple regression, Geographically weighted regression, Simultaneous equation demand model, ARIMA, Fuzzy-logic, Agent based approach, Judge mental forecasts, End-use approaches, Econometric time series.

Long-term forecasts; Regression with Bayesian Entropy, Uni variate time series, System Dynamics, Land use based models, IWR-MAIN, PODIUMSIM, Hybrid approach.

System Dynamics modeling has been chosen because it considers the socio-economic factors which are dynamic in nature. It is an iterative technique which helps to arrive at the accurate demand. System dynamics concept which express as Systems thinking, it focuses mainly on formulating the model structures and in-depth analysis of problem objectives. It connects with the four dimensions of sustainability and interacts with the model formulation and makes the long terms management plan.

\subsection{Water Demand Estimation Using System Dynamics}

Accordingly, the overall goal of this study is to thoroughly reviewing the water demand estimation model and formulate the System dynamics model for Madurai city which considers the socio-economic factors which are not being stable. System dynamics modeling procedures are Problem identification, Model formulation, Simulation and Validation. For formulating the system dynamics model, so many Software are available such as Vensim, iThink, Stella and Powersim. In this study, Vensim PLE software has been used to formulate, simulate the model and to estimate the water demand.

Vensim : Much more powerful, and quite flexible if you have access to using subscripts. If you are working on real big projects this it is good, but the visualization is really old fashioned.

\section{METHODOLOGY}

In the view of nature of the problem and available case studies, a tool is designed and checked with reliable data available from the field.

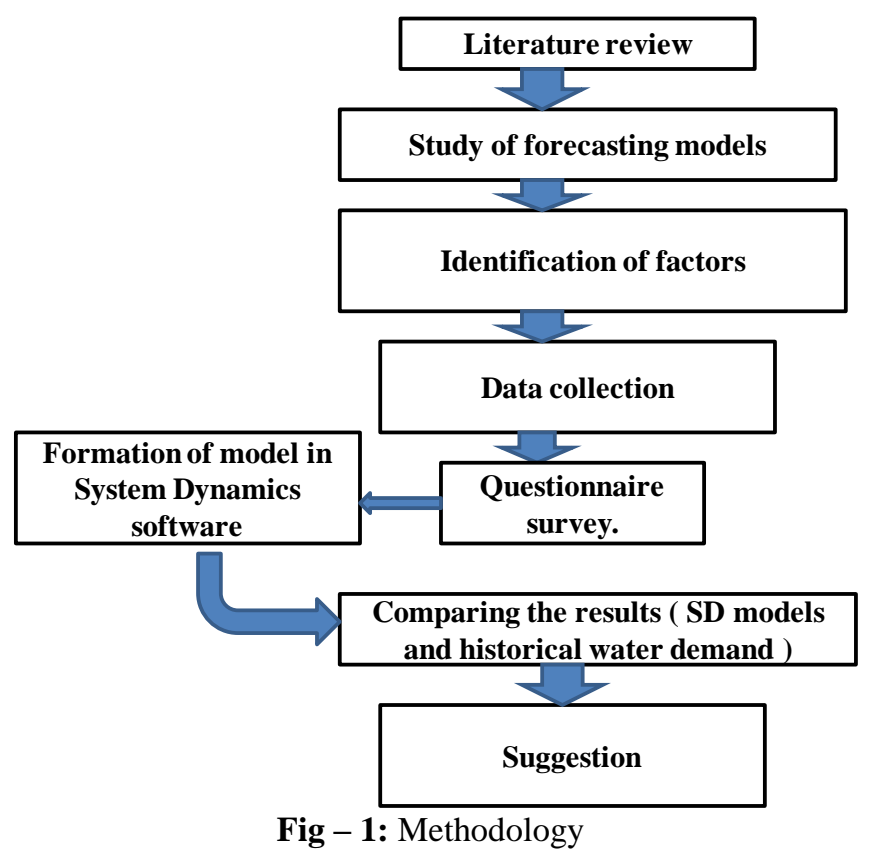

\section{STUDY AREA DESCRIPTION}

Madurai City, located in South Central Tamil Nadu, is the third largest city after Chennai and is the headquarters of Madurai District. As the limits of Madurai City Corporation have been extended from 72 wards to 100 wards in the year 
of 2011, the City is required to develop and improve its infrastructure in the added areas. At present, the water supply for the newly added areas does not meet the percapita water demand required as CPHEEO norms. Hence the Madurai city corporation had proposed to execute a Water Supply Scheme for the newly added areas under the JnNURM II scheme or under Integrated Urban Development Mission (IUDM). Water supply Distribution System for the newly added areas is one of the priority sectors for infrastructure improvement under these schemes. There has been a significant increase in both the population and the number of households in Madurai city and this has enhanced the need for a more efficient water distribution system to improve the water supply to the prospective consumers and enhance the coverage. At present the total population of the City, according to 2011 census, for the Madurai city is $14,70,754$ persons.

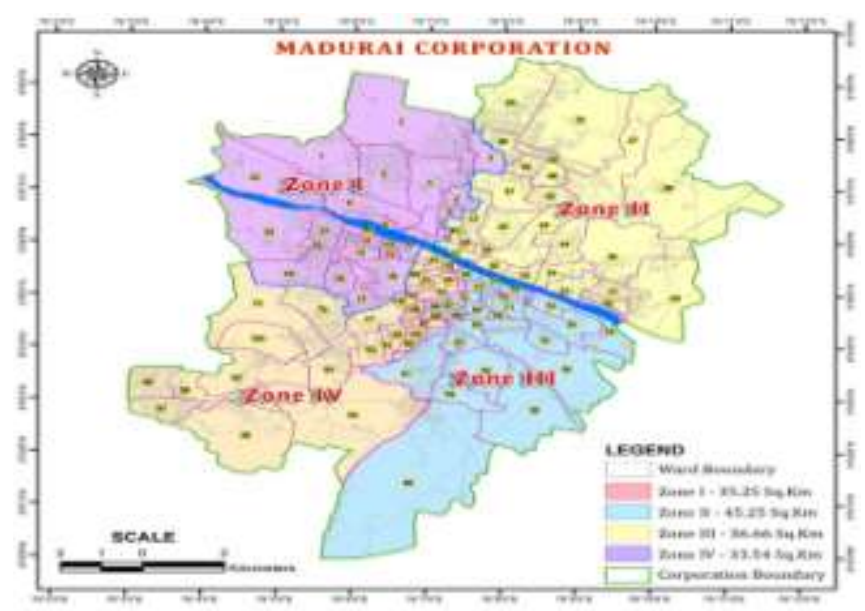

Fig - 2: Madurai Corporation Map (100 Wards)

\subsection{Madurai and its Water Resources}

The main source for Madurai Water supply is Vaigai Dam. The total storage capacity of Vaigai dam is $6,091 \mathrm{mcft}$. At present, Madurai city has a water supply scheme for 174 MLD, but due to improper monsoon and other factor, the corporation able to supply 105 MLD of water to the system. In that 87 MLD of water drawing Vaigai dam located $65 \mathrm{~km}$ away from Madurai city, under Vaigai water supply scheme I and II.

At present, the city supplies at an average of 103 liters per capita by once in 4 days. The estimated Non-Revenue water at present is at $35.58 \%$ of total water supply to the system. In that real loss account at major portion i.e. $26.50 \%$. Unauthorized consumption, theft is the second major loss in the water supply system.

At present the demand for Madurai city is 209 MLD, with available existing water resources, the city corporation supply only 115 MLD. Based on the calculation for water demand compared with water supply, at present the city has a shortage of 94 MLD of water. Because of importance in Industries and tourism and population growth the water demand for Madurai will increase gradually on the coming years.

\subsection{Water Resource in Domestic Users}

In Madurai, as per Census Reports 2011, the 68\% of Households having direction Tap Connection, In North side of the city, and the Tap connection having less connection compares to the south side of the city. In south side most of Tap connections are within the premises. Hand pumps are used by $17 \%$ of Households in Madurai. Tube well, having a share of $9 \%$ of Households. Compare to the south side, north side of corporation areas is used more percentage of tube wells, because in south side most of the wards ground water tables are depleted. And In all other sources, the Households depend on water supply through tanker Lorries. On the North side, $18 \%$ of households depend on tanker supply for their needs, because there is no water supply infrastructure facility in the newly developed areas.

As per the survey done by Madurai Corporation, $64 \%$ of the population are satisfied with the quantity of water supplied, nearly $47 \%$ are happy with the quality of water supplied, and $34 \%$ not satisfied with the quality of water supply, remaining are neither satisfied nor dissatisfied with the quality of water supply.

\subsection{Factors Impacting Water Demand}

The following are the major factors affecting water demand in Madurai,

Table -1: Factors impacting Water Demand

\begin{tabular}{|l|l|}
\hline Climate & Socio- Economic elements \\
\hline Weather & Population growth. \\
\hline Rainfall pattern & $\begin{array}{l}\text { Population density - death and } \\
\text { birth rate, Emigration, } \\
\text { Immigration. }\end{array}$ \\
\hline $\begin{array}{l}\text { Evapo - transpiration } \\
\text { rate }\end{array}$ & $\begin{array}{l}\text { people and their Economic } \\
\text { status, Occupancy rate, Size of } \\
\text { the city. }\end{array}$ \\
\hline $\begin{array}{l}\text { Maximum daily } \\
\text { temperature }\end{array}$ & Cost of water, Tariffs. \\
\hline Wind speed & Tourism. \\
\hline Precipitation & $\begin{array}{l}\text { Water consumption, policy } \\
\text { and management. }\end{array}$ \\
\hline Water supply system & $\begin{array}{l}\text { Source substitution and Water } \\
\text { usage practices }\end{array}$ \\
\hline pressure and equality & Effluent reuse \\
\hline Non revenue water & Rainwater storage tank \\
\hline Leakages & Waste water generation rate. \\
\hline
\end{tabular}




\begin{tabular}{|l|l|}
\hline $\begin{array}{l}\text { Water storage } \\
\text { infrastructures and } \\
\text { capacity. }\end{array}$ & Industrial reuse. \\
\hline $\begin{array}{l}\text { Availability of } \\
\text { resources - ground } \\
\text { water and surface } \\
\text { water }\end{array}$ & \\
\hline $\begin{array}{l}\text { Unauthorized use of } \\
\text { water. }\end{array}$ & \\
\hline
\end{tabular}

\section{System Dynamics Simulation Models}

\subsection{Basic Concepts}

System Dynamics modeling is an iterative technique which helps to solve the complex problems by considering the more variables and criteria. It is also an decision making tool. It has the process of developing the causal loop diagramming. It shows the relationship between the selected variables and shows the interaction between them. Then another digram is stock and flow digram, which integrates the submodels with the variables, attributes and feeding data to finally generate/quantify the expected result by running the model for several times.

System dynamics model initially plays an major role in the business systems, then in some social and environmental systems. For finding water demand estimation, System dynamics model were rarely used because the factors includes in the estimations are not stable. For formulating the system dynamics model, so many Software are available such as Vensim, iThink, Stella and Powersim. In this study, Vensim PLE software has been used to formulate, simulate the model and to estimate the water demand.

Vensim: Much more powerful, and quite flexible if you have access to using subscripts. If you are working on real big projects this it is good, but the visualization is really old fashioned.

\subsection{Population Sub-Model}

This sub-model represents the population of the Madurai City. The population at time $t$ is mathematically represented as:

- $P(t)=P(0)+\int\left[r_{b}-r_{d}\right] d t$

- Population $(P)$,

- Increased by births $\left(\mathrm{r}_{\mathrm{b}}\right)$

- Decreased by deaths $\left(r_{d}\right)$ (refer Figure).

\subsection{Households Sub-Model}

The households sub-model consists of two stocks, namely, households with basic supply (HBS) and connected households $(\mathrm{CH})$ (refer Figure 3).

- $H B S(t)=H B S(0)+\int\left[r_{g b s^{-}} r_{c}\right] d t$

- $\quad T I H=T H-(H B S+C H)$
- $\quad C H(t)=C H(0)+\int[r c] d t$

- $r_{c}=H B S * N M C * E W S R$

- $W S R=A W C H / B A W C H$

Total number of informal households $(T I H)$

Growth rate of households with basic supply (GRBS).

Total number of households $(T H)$

Household connection rate $\left(r_{c}\right)$

Net growth of households with basic supply $\left(\mathrm{r}_{\mathrm{gbs}}\right)$

Households with basic supply $(H B S)$

Connected households $(\mathrm{CH})$.

Connection Rate $\left(r_{c}\right)$

Effect of water savings on municipal connections (EWSR)

\subsection{Potable Water Supply Sub-Model}

The raw water stock $(R W)$ is influenced by three flows, raw water purchases $\left(\mathrm{r}_{\mathrm{rwp}}\right)$, rainfall into raw water reservoirs $\left(r_{\mathrm{rf}}\right)$ and water treatment rate $\left(\mathrm{r}_{\mathrm{tm}}\right)$.

The mathematical representation of this is:

- $R W(t)=R W(0)+\int\left[\left(r_{r w p}+r_{r f}\right)-r_{t m}\right] d t$

The potable water $(P W)$ stock is influenced by water treatment rate $\left(\mathrm{r}_{\mathrm{tm}}\right)$, potable water losses $\left(\mathrm{r}_{\mathrm{lo}}\right)$ and potable water consumption $\left(\mathrm{r}_{\mathrm{pwc}}\right)$, represented as:

- $\quad P W(t)=P W(0)+\int\left[\left(r t m-r_{l o}-r_{p w c}\right)\right] d t$

- $r_{p w c}=\min (M P W,(T H D * P W / T A S))$

- $\quad r_{r w p}=M R W-\left(R W / t_{r w}\right)$

- $\quad r_{t m}=\min (M P W, P R)$

- $r_{r s}=\min ((T H S t R-R W T), R F A)$

- $\quad r_{r w c}=\min (R W T,(T H D * R W T / T A S))$

- $T H S t R=T N T * A C R$

- $R F A=R F^{*} T H C R$

The rate of potable water consumption $\left(\mathrm{r}_{\mathrm{pwc}}\right)$

Raw water stock $(R W)$

The total household demand (THD),

The amount of potable water $(P W)$,

Maximum capacity of the potable water reservoirs $(M P W)$,

Total available supply of water (TAS)

Raw water purchases ( $\mathrm{r}_{\mathrm{rwp}}$ )

Rainfall into raw water reservoirs $\left(r_{r f}\right)$

Maximum capacity of the raw water reservoirs $(M R W)$

Amount of raw water $(R W)$

Water treatment works at its maximum capacity (WTC).

The treatment process rate $(T P R)$

The available raw water $(R W)$

Production $(P R)$

Treatment rate $\left(\mathrm{r}_{\mathrm{tm}}\right)$

Rainwater volume in storage tanks $(R W T)$

Reduced by rain water consumption $\left(\mathrm{r}_{\mathrm{rwc}}\right)$.

The rainwater storage rate $\left(r_{r s}\right)$

Amount of rainfall in ML (RFA)

The total household storage capacity for rainwater harvesting (thstr)

Number of tanks (TNT)

Average capacity of rainwater tanks $(A C R)$

Product of rainfall $(R F)$ and

Total household catchment for rainwater (THCR). 


\section{RESULT AND DISCUSSION}

As per analysis of existing water supply system in Madurai Corporation, the augmentation of new water resource is a very urgent concern to meet the public water supply requirement and demand creates in Madurai city, for bringing completely new water resources to the city is very difficult, The existing water resources are completely depend on Vaigai River and Vaigai Dam, but Vaigai is not Perennial River, the flow in river is only in monsoon season.

The study discussed about the municipal water demand of Madurai city (100 wards). The total demand considers here as bulk losses and Household demand of municipal areas. Whereas, the water supply also projected with the factors of total no of Households, HH with basic supply, Connected $\mathrm{HH}$ and average use of water in HH. The total supply in each decade does not meet the required demand. It seems to be deficit of water is more. Losses also increase in each decade. The main causes for this deficiency are increase in population, Tourism rate and insufficient rainfall, climate change etc., System Dynamics modeling forecasted the water demand for Madurai city with the help of SocioEconomic factors and some other common factors.

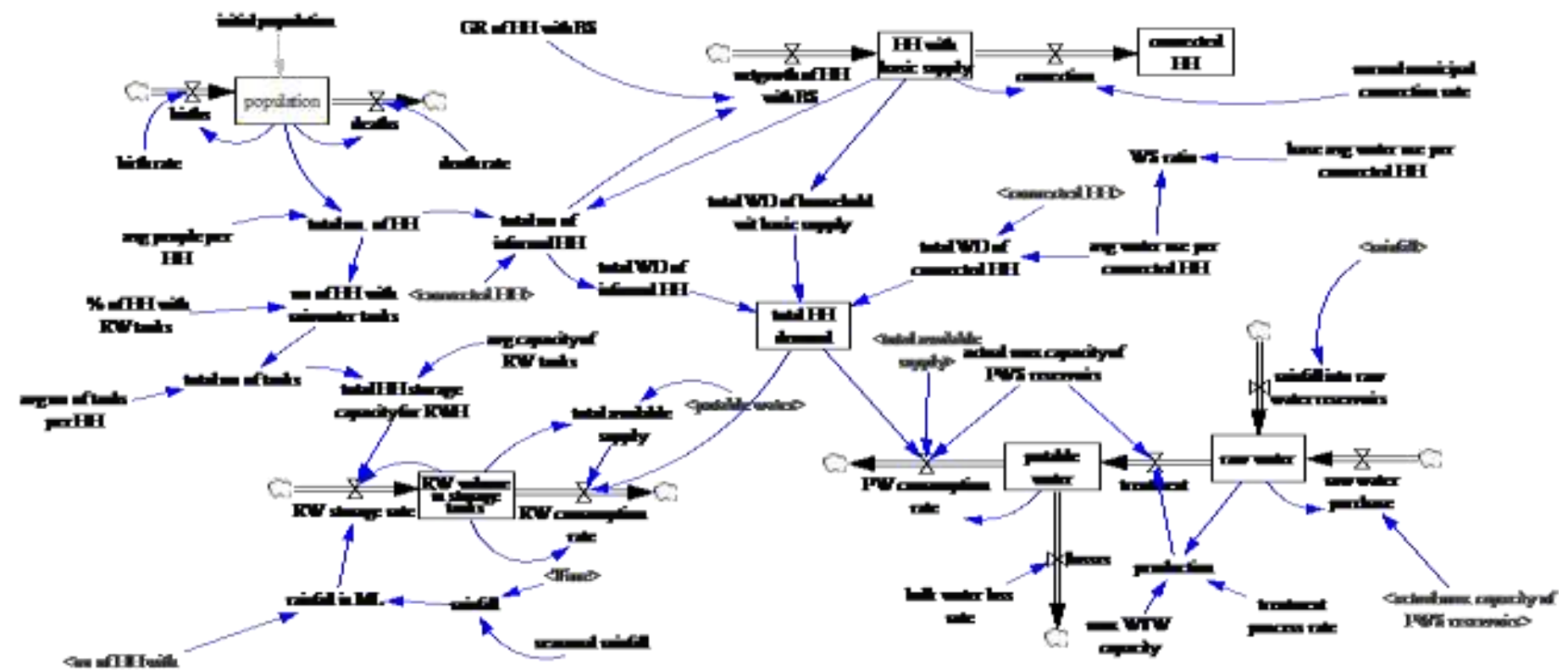

Fig -3: Stock and Flow Diagram For Water Demand Forecasting of Madurai City

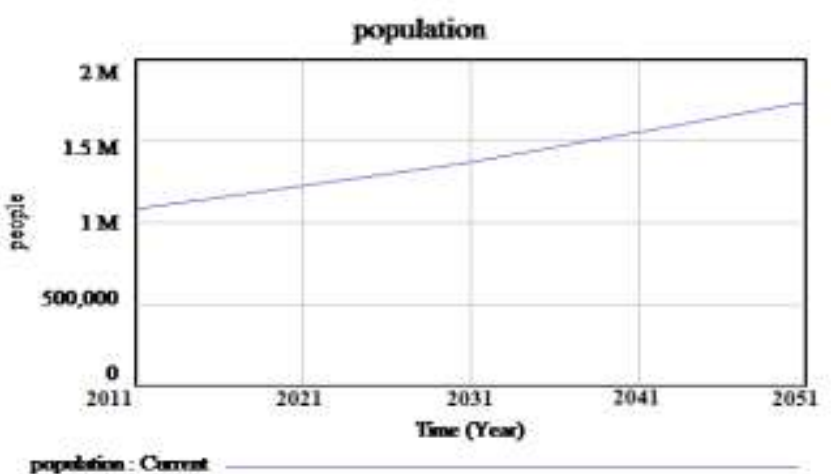

Fig -4: Population

Table -2: Population Forecasting

\begin{tabular}{|l|l|l|}
\hline S. No & Year & People (in lakhs) \\
\hline 1. & 2011 & 11.4 \\
\hline 2. & 2021 & 12.5 \\
\hline 3. & 2031 & 14.2 \\
\hline 4. & 2041 & 16.2 \\
\hline 5. & 2051 & 17.5 \\
\hline
\end{tabular}

Household with Basic Supply by 2041 for 100 wards of Madurai city:

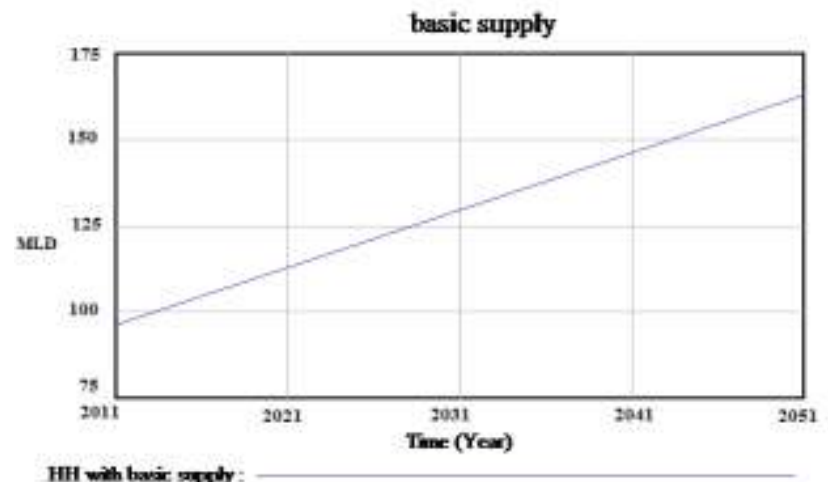

Fig -5: Basic Supply

Table-3: Basic Household Supply

\begin{tabular}{|l|l|l|}
\hline S.No & Year & Supply(in MLD) \\
\hline 1. & 2011 & 98 \\
\hline 2. & 2021 & 111 \\
\hline 3. & 2031 & 128 \\
\hline 4. & 2041 & 147 \\
\hline 5. & 2051 & 166 \\
\hline
\end{tabular}


Household Demand by 2041 for 100 wards of Madurai city:

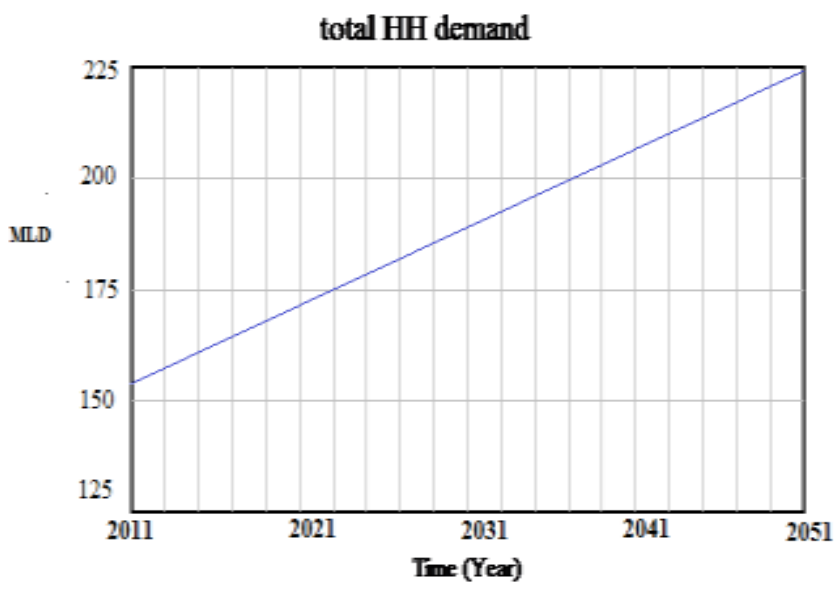

Fig -6: Total HH Demand

Table -4: Total HH Demand

\begin{tabular}{|l|l|l|}
\hline S.No & Year & Demand (in MLD) \\
\hline 1. & 2011 & 154 \\
\hline 2. & 2021 & 172 \\
\hline 3. & 2031 & 188 \\
\hline 4. & 2041 & 210 \\
\hline 5. & 2051 & 225 \\
\hline
\end{tabular}

Losses by 2041 for 100 wards of Madurai city:

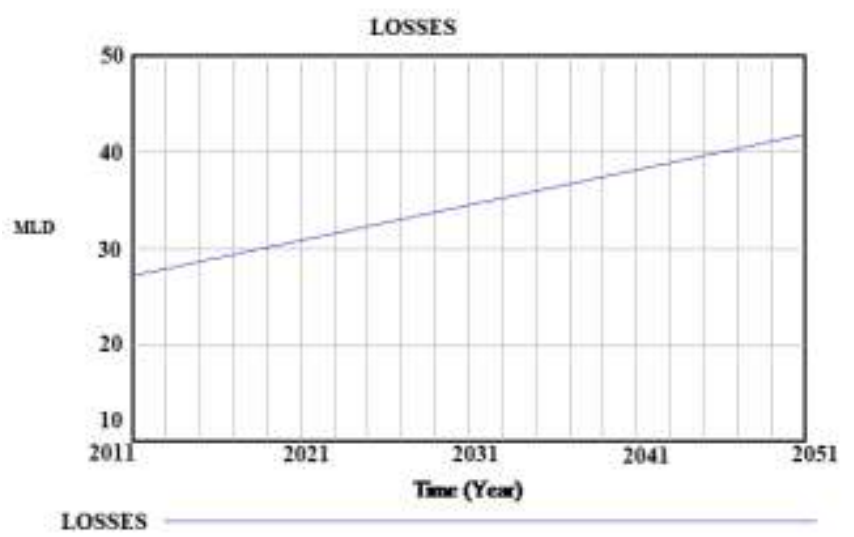

Fig -6: Losses

Table -5: Losses

\begin{tabular}{|l|l|l|}
\hline S.No & Year & Losses (in MLD) \\
\hline 1. & 2011 & 27 \\
\hline 2. & 2021 & 31 \\
\hline 3. & 2031 & 35 \\
\hline 4. & 2041 & 38 \\
\hline 5. & 2051 & 42 \\
\hline
\end{tabular}

Total Demand (HH and Losses) by 2041 for 100 wards of Madurai city:

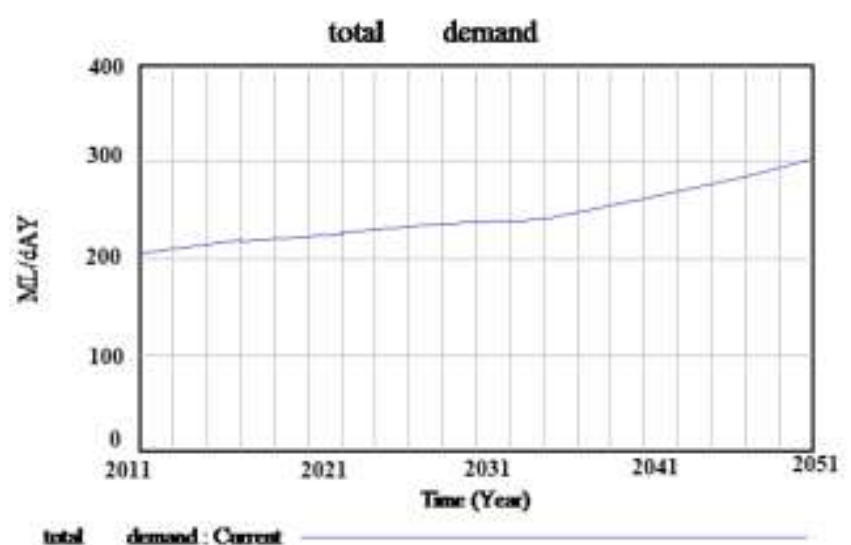

Fig -6: Total Demand

\begin{tabular}{|l|l|l|}
\hline S.No & Year & Losses (in MLD) \\
\hline 1. & 2011 & 209 \\
\hline 2. & 2021 & 230 \\
\hline 3. & 2031 & 249 \\
\hline 4. & 2041 & 278 \\
\hline 5. & 2051 & 300 \\
\hline
\end{tabular}

Fig -7: Total Demand

\section{WATER DEMAND ESTIMATION}

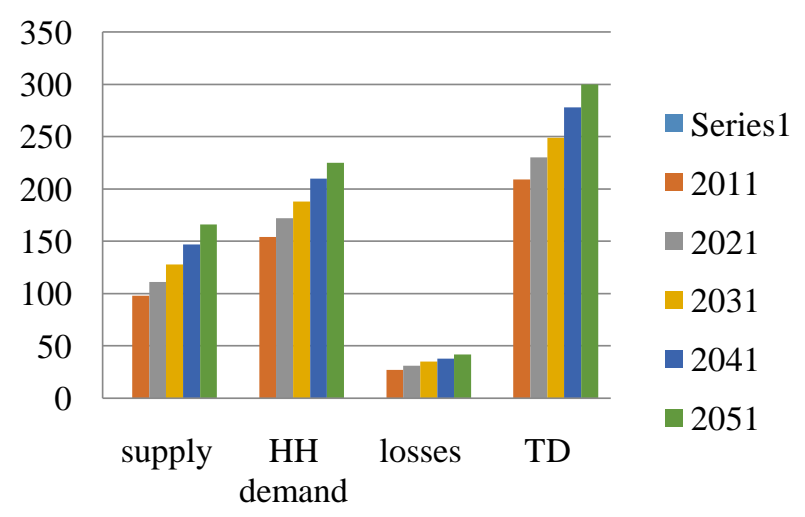

Chart -1: Consolidated Water Demand Estimation For Madurai City

\section{CONCLUSION}

A detailed literature review was carried out to study the different water demand estimation models and to identify the factors influencing water demand estimation. It has been identified that sustainable and accurately predictable water demand estimation model is System Dynamics Model. The System Dynamics model has been formulated using the software called Vensim PLE for the study area. The water demand has been projected by 2040 for the study area.

System Dynamics model has been simulated to find the water demand. It has taken the several runs to estimate the appropriate water demand. The forecasted water demand increases in each decade. Water supply doesn't able to satisfy the required demand of water and simultaneously 
losses also increases. Identified future water demand for the study area has been validated by using the historical demand data and projected demand data using simple mathematical calculations. It has been suggested that the rainwater harvesting policy must be followed strictly. The losses due to Physical failure, improper maintenance, unauthorized connection etc., It has to strictly monitored to reduce the loss rate and manage the required demand.

\section{REFERENCES}

[1] AbduSselam Altunkaynak, Mehmet Ozger and Mehmet Cakmakci (2005) "Water Consumption Prediction of Istanbul City by Using Fuzzy Logic Approach" Water Resources Management, Reviews-19: 641-654.

[2] Ashu Jain and Lindell E. Ormsbee (2002) "Short-term Water demand forecast modeling techniquesCONVENTIONAL METHODS VERSUS AI" Journal (American Water Works Association), Vol. 94, No. 7, pp. 64-72.

[3] Alaa H. Aly, M.ASCE and Nisai Wanakule, M.ASCE (2004) "Short-Term Forecasting for Urban Water Consumption" Journal of Water Resource Planning and Management, 130(5): 405-410.

[4] Álvaro-Francisco Morote, María Hernández (2016) "Urban sprawl and its effects on water demand: A case study of Alicante, Spain" Land Use Policy, Reviews-50 352-362.

[5] S. Barua, A.W.M. NG, S. Muthukumaran, F. Huang, P. Roberts and B.J.C. Perera (2013) "Modeling water use in schools: a comparative study of quarterly and monthly models" The International Congress on Modelling and Simulation, Adelaide, Australia, www.mssanz.org.au/modsim2013.

[6] Cheng Qi, Ni-Bin Chang (2011) "System dynamics modeling for municipal water demand estimation in an urban region under uncertain economic impacts" Journal of Environmental Management Reviews 92 (1628-1641)

[7] D'Hont F (2013). “A system dynamics model for deepening the understanding of Greater Kirkwood's water supply system, South Africa". Bachelor project phase 2, BSc Technische Bestuurskunde, Faculty of Technology, Policy Analysis and Management, Delft University of Technology, the Netherlands.

[8] Forrester, J. W. (2007). "System Dynamics - the Next Fifty Years". System Dynamics Review, 23, (359370).

[9] Gunhui Chung, Joong Hoon Kim, and Tae-Woong Kim (2008) "System Dynamics Modeling Approach to Water Supply System" Journal of Civil Engineering Reviews 12(4) (275-280).

[10] Heejun Chang and Lily House-Peters (2011) "Urban Water Demand Modeling: Review of Concepts, Methods, and Organizing Principles" Water Resources Research, VOL. 47, W05401, doi:10.1029/2010WR009624.

[11] https://esa.un.org/unpd/wup/publications/files/wup2014 -highlights.Pdf

[12] Jan Adamowski, Hiu Fung Chan, Shiv O. Prasher, Bogdan Ozga-Zielinski, and Anna Sliusarieva (2012)
"Comparison of multiple linear and nonlinear regression, autoregressive integrated moving average, artificial neural network, and wavelet artificial neural network methods for urban water demand forecasting in Montreal, Canada" Water Resources Research, Vol. 48, W01528.

[13] Janez Sušnik , Lydia S. Vamvakeridou-Lyroudia, Dragan A. Savić, Zoran Kapelan "Integrated System Dynamics Modeling for water scarcity assessment: Case study of the Kairouan region" Science of the Total Environment Reviews 440 (290-306)

[14] Jai K Clifford Holmes, Jill H Slinger, Josephine K Musango, Alan C Brent \& Carolyn G Palmer(2014) "Using System Dynamics to Explore the Water Supply and Demand Dilemmas of a Small South African Municipality" System Dynamics Society.

[15] Krystyna A. Stave (2003) "A system dynamics model to facilitate public understanding of water management options in Las Vegas, Nevada" Journal of Environmental Management 67 (2003) 303-313.

[16] Magnus Moglia, Pascal Perez, Stewart Burn (2010) "Modelling an urban water system on the edge of chaos" Environmental Modelling \& Software, Reviews$25,1528 \mathrm{e} 1538$.

[17] Mahdi Zarghami and Simin Akbariyeh (2012) "System dynamics modeling for complex urban water systems: Application to the city of Tabriz, Iran" Resources, Conservation and Recycling Reviews 60 (99-106).

[18] Mukesh TIWARI, Jan ADAMOWSK, Kazimierz ADAMOWSKI (2016) "Water demand forecasting using extreme learning machines" Journal of Water and Land Development No. 28 (I-III): 37-52 PL ISSN 1429-7426.

[19] Murat Yalçıntaş, Melih Bulu, Murat Küçükvar and Hamidreza Samadi (2015) "A Framework for Sustainable Urban Water Management through Demand and Supply Forecasting: The Case of Istanbul" Sustainability 2015, 7, 11050-11067; doi:10.3390/su70811050.

[20] Stuart White, Jim Robinson, Dana Cordell, Meenakshi Jha and Geoff Milne (2003) "Urban Water Demand Forecasting \& demand Management" Water Services Association of Australia - Occasional Paper No. 9.

[21] Vincent C.Tidwell, Howard D. Passell, Stephen H. Conrad and Richard P. Thomas (2004) "System dynamics modeling for community-based water planning: Application to the Middle Rio Grande" Aquat. Sci.Reviews- 66, 357-372, 10151621/04/040357-16, DOI 10.1007/s00027-004-0722-9.

[22] Wang Xiao-Jun, Zhang Jian-Yun, Amgad Elmahdi, He Rui-Min \& Zzhang Li-Ru \& Chen Feng (2011) "Water demand forecasting under changing environment: a System Dynamics approach" Risk in Water Resources Management (347).

[23] Xi Xi, Kim Leng Poh (2013) "Using system dynamics for sustainable water resources management in Singapore" Procedia Computer Science Reviews 16 (157-166).

[24] Xuehua Zhang and Hongwei Zhang (2014) “A System Dynamics Approach to Urban Water Demand 
Forecasting -A Case Study of Tianjin" http://www.paper.edu.cn.

[25] Yilin Zhuang (2014) "A System Dynamics Approach to Integrated Water and Energy Resources Management".

[26] ZHAI Yuanzheng, WANG Jinsheng, TENG Yanguo, ZUO Rui (2012) "Water demand forecasting of Beijing using the Time Series Forecasting Method" Journal of Geographical Science, 22(5): 919-932 DOI: 10.1007/s11442-012-0973-7. 